\title{
Pemberdayaan Perempuan Melalui Program Zakat Produktif di Desa Bukit Peninjauan I Kecamatan Sukaraja Kabupaten Seluma
}

\author{
Nilda Susilawati, M. Ag \\ email: nildaqila@gmail.com \\ IAIN Bengkulu \\ Jl. Raden Fatah Pagar Dewa Kota Bengkulu
}

\begin{abstract}
Women's Empowerment Through Productive Zakat Program in Bukit Peninjau I Village, Sukaraja Sub-District, Seluma District. The productive zakat program is one of the efforts to empower women in an effort to improve the family economy. Women as part of the family are required to support the family economy in order to survive. The ability of women to become the backbone of the family must be sustained by the ability both financially and expertise in running the profession. Some productive zakat empowerment programs that can be developed in Bukit Peninjau I Village, Sukaraja Subdistrict, Seluma District, are providing assistance for vegetable business capital, providing plant seeds, fertilizer and agricultural equipment, home industry training, and entrepreneurship training for young women.
\end{abstract}

Keywords: women's empowerment, productive zakat program

\begin{abstract}
Abstrak: Program zakat produktif merupakan salah satu upaya pemberdayaan perempuan dalam upaya peningkatan ekonomi keluarga. Perempuan sebagai bagian dalam keluarga diharuskan menjadi penopang ekonomi keluarga atau penunjang ekonomi agar dapat bertahan hidup. Kemampuan perempuan untuk menjadi tulang punggung keluarga mesti ditopang oleh kemampuan baik secara finansial maupun keahlian dalam menjalan profesi. Beberapa program pemberdayaan zakat produktif yang bisa dikembangkan di Desa Bukit Peninjauan I Kecamatan Sukaraja kabupaten Seluma yaitu pemberian bantuan modal usaha sayuran, pemberian bibit tanaman, pupuk dan peralatan pertanian, pelatihan home industri dan pelatihan kewirausahaan bagi perempuan muda.
\end{abstract}


Jurnal Hawa Vol. I No. I Januari-Juni 20I9

Kata Kunci: pemberdayaan perempuan, program zakat produktif

\section{A. Pendahuluan}

Relasi antara kemiskinan dan keterbelakangan dengan beberapa aspek ekonomi dan non ekonomi menurut Tedora terdapat tiga komponen utama penyebab keterbelakangan dan kemiskinan masyarakat adalah faktor rendahnya taraf hidup, rendahnya rasa kepercayaan diri, terbatasnya kebebasan. Tiga aspek tersebut memiliki hubungan timbal balik. Rendahnya taraf hidup disebabkan oleh rendahnya tingkat pendapatan. Rendahnya pendapatan disebabkan oleh rendahnya produktivitas tenaga kerja. Rendahnya produktivitas disebabkan tingginya pertumbuhan tenaga kerja, tingginya angka pengangguran, dan rendahnya investasi perkapita. ${ }^{1}$ Dengan rendahnya faktor-faktor tersebut menyebabkan rendahnya aktivitas ekonomi yang dapat dilakukan oleh masyarakat. Dengan rendahnya aktivitas ekonomi yang dapat dilakukan berakibat terhadap rendahnya produktivitas dan pendapatan yang diterima.
Pada gilirannya pendapatan tersebut tidak mampu memenuhi kebutuhan fisik minimum yang menyebabkan terjadinya proses kemiskinan. ${ }^{2}$ Kemiskinan yang dirasakan oleh sebagian masyarakat, mengharuskan keikutsertaan perempuan sebagai bagian dari usaha penemenuhan kebutuhan hidup. Perempuan memainkan peran yang sama dengan kaum laki-laki dalam beragai profesi sebagai bentuk kesetaraan gender.

Kesetaraan gender akan memperkuat kemampuan negara untuk berkembang, mengurangi kemiskinan, dan memerintah secara efektif. Dengan demikian mempromosikan kesetaraan gender adalah bagian utama dari strategi pembangunan dalam rangka untuk memberdayakan masyarakat yaitu perempuan dan laki-laki untuk mengentaskan diri dari kemiskinan dan meningkatkan taraf hidup mereka. ${ }^{3}$ Sehingga fungsi dari laki-laki dan 
perempuan setara khususnya dalam banyak bidang profesi.

Perempuan memiliki peran yang sangat penting dalam sebuah rumah tangga, tidak hanya sebagai ibu yang memiliki kewajiban untuk mendidik dan mengurus anak dan rumah tangga, namun sebagian wanita lainnya juga berperan dalam mencari nafkah untuk memenuhi kubutuhan hidup sehari-hari. Berbagai profesi yang dijalankan perempuan agar mampu menopang ekonomi keluarga. Namun tidak semua perempuan bisa menjalankan profesi di luar rumah karena larangan suami atau keadaan yang tidak memungkinkan. Sehingga para perempuan kadang mencari alternatif lain untuk membantu ekonomi keluarga melalui kegiatan yang bisa dilakukan di rumah tanpa harus meninggalkan keluarga. Sehingga tugas perempuan untuk menjaga keluarga tidak terabaikan akibat melakukan profesi di luar rumah.

Fungsi perempuan menjadi sangat penting dalam struktur kehidupan dalam rumah tangga maupun masyarakat. Karena itu perempun harus mampu diberdayakan dengan kemampuan dan keadaan yang dijalani sebagai elemen penting dalam peningkatan ekonomi keluarga dan masyarakat. Pemberdayaan perempuan menjadi salah satu alternatif untuk menempatkan perempuan sebagai bagian dari usaha pemerintah untuk meningkatkan ekonomi salah satunya melalui Badan Amil Zakat Nasional melalui program pemberdayaan zakat.

Zakat sebagai salah satu kewajiban bagi umat Islam memiliki peran yang cukup besar dalam upaya pemberdayaan mustahik. Dana zakat yang disalurkan dapat menjadi sumber modal dan biaya pelatihan bagi mustahik, hal ini sebagai bentuk pemberdayaan zakat produktif. Melalui program zakat para perempuan di Desa Bukit Peninjauan I Kecamatan Sukaraja Kabupaten Seluma dapat membantu ekonomi keluarga, karena rata-rata penduduk banyak yang berprofesi sebagai buruh dan petani. ${ }^{4}$ Melalui dana zakat yang bersumber dari muzakki 
Jurnal Hawa Vol. I No. I Januari-Juni 20IS

dapat membantu masyarakat dalam menopang ekonomi, karena menjadi kewajiban umat Islam yang memiliki harta untuk mengeluarkan zakatnya sebagaimana dalam firman Allah:

"Dan orang-orang yang beriman, laki-laki dan perempuan, sebagian mereka (adalah) adalah menjadi penolong bagi sebagian yang lain. Mereka menyuruh (mengerjakan) yang ma'ruf, mencegah dari yang mungkar, mendirikan sholat, menunaikan zakat dan mereka taat kepada Allah dan Rasul-Nya, mereka itu akan diberi rahmat oleh Allah: Sesungguhnya allah Maha Perkasa lagi Maha Bijaksana.(QS. AtTaubah: 71)

Salah satu upaya pemberdayaan zakat produktif dapat dilakukan di Desa Bukit Peninjauan I yang mempunyai luas $327 \mathrm{ha} / \mathrm{m} 2,5$ dengan luas $70 \%$ dari lahan dimanfaatkan oleh masyarakat sebagai lahan pertanian seperti palawija, sawah, karet dan sawit sedangkan $30 \%$ dijadikan sebagai pemukiman bagi warga. Dengan batas wilayah sebelah barat berbatasan dengan Desa Sumber Arum, sebelah timur dengan Desa Sari Mulya, sebelah utara dengan Desa Sido Luhur dan sebelah seatan berbatasan dengan Desa Sumber Makmur.

Jumlah penduduk Desa Bukit Peninjauan I tahun 2018 berjumlah 1.818 jiwa, laki-laki berjumlah 940 jiwa dan perempuan 874 jiwa, dengan wilayah dibagi menjadi 7 dusun yaitu Dusun 1, Dusun 2, Dusun 3, Dusun 4, Dusun 5, Dusun 6 dan Dusun 7. Jumlah penduduk terbanyak terdapat di dusun 6 yang mencapai 293 jiwa atau 88 KK. Agama yang dianut masyarakat Desa Bukit Peninjauan I mayoritas beragama Islam sebanyak 1.788 jiwa dan kristen 30 jiwa. Sementara sarana dan prasarana ibadah terdapat 3 mesjid, 5 musholla dan 1 gereja yang dimanfaatkan oleh masyarakat untuk melakukan ibadah dan kegiatan keagamaan lainnya. Mayoritas mata pencaharian penduduk merupakan petani sawit, sawah dan karet berjumlah 452 orang, sedangkan sebagian ada yang berprofesi sebagai karyawan swasta, wiraswasta, PNS dan buruh harian pada kebun atau 
perkebunan yang ada di sekitar Desa Bukit Peninjauan I. Tingkat pendidikan masyarakat bervariasi mulai dari SD hingga S2, tamatan SD berjumlah 621 jiwa, SLTP berjumlah 407 jiwa, SLTA berjumlah 219 jiwa, S1 berjumlah 27 jiwa dan S2 berjumlah 2 jiwa sementara sisanya belum sekolah atau sedang menempuh pendidikan setingkat Sekolah Dasar. ${ }^{6}$

Gambaran

kondisi

masyarakat Desa Bukit Peninjauan I Kecamatan Sukaraja Kabupaten Seluma di atas menunjukkan bahwa secara ekonomi masyarakat mayoritas petani atau buruh lepas sangat membutuhkan bantuan dari pemerintah dalam peningkatan ekonomi salah satunya melalui program pemberdayaan zakat produktif terutama bagi perempuan dalam membantu peningkatan ekonomi keluarga.

\section{B. Metode Penelitian}

Metode yang digunakan dalam penelitian ini field reseach dengan pendekatan kualitatif. Data hasil penelitian lapangan dioleh kemudian disajikan dalam bentuk deskriptif kualitatif untuk menggambarkan fenomena yang terjadi di lapangan dan program pemberdayaan zakat apa yang tepat diterapkan di Desa Bukit Peninjuan I Kecamatan Sukaraja Kabupaten Seluma. Metode yang digunakan untuk mengumpulkan data melalui observasi dan wawancara untuk memperoleh data yang berkaitan dengan kondisi masyarakat desa, kondisi ekonomi dan mata pencaharian serta potensi pengembangan program pemberdayaan zakat yang tepat dilaksanakan di Desa Bukit Peninjauan I.

Teknik analisis data menggunakan data reduction dengan memilih hal-hal pokok atau penting berkaitan dengan program pemberdayaan perempuan dan data yang ada direduksi untuk menggambarkan kondisi yang ada di Desa Bukit Peninjauan I. Data display digunakan dalam bentuk uraian singkat yang bersifat naratif, sehingga memudahkan untuk menyampaikan gambaran yang terjadi dan program pemberdayaan zakat yang tepat diterapkan dan selanjutnya 
Jurnal Hawa Vol. I No. I Januari-Juni 2019

conclusion drawing merupakan penarikan kesimpulan dari dari data-data yang ada di Desa Bukit Peninjauan I dan gambaran secara deskirptif berdasarkan hasil penelitian yang telah dilakukan.

\section{Tinjauan Pustaka}

\section{Pemberdayaan Perempuan}

Pemberdayaan perempuan merupakan upaya untuk mewujudkan kesetaraan peran, akses, dan kontrol perempuan dan laki-laki di semua bidang pembangunan.

Programprogram pemberdayaan perempuan yang dilakukan oleh pemerintah dan masyarakat selama ini merupakan upaya untuk senantiasa mewujudkan terciptanya dan terdistribusinya manfaat pembangunan bagi laki-laki dan perempuan secara berimbang. Berbagai langkah dapat dilakukan untuk menciptakan kesetaraan lakilaki dan perempuan atau kesetaraan gender, antara lain dengan mengembangkan kewirausahaan keluarga sehingga dapat terwujud peran yang seimbang antara laki-laki dan perempuan dalam keluarga untuk

bersama-sama

membangun

dan

mengembangkan perekonomian keluarga demi mencapai kesejahteraan keluarga ${ }^{7}$

Pemberdayaan perempuan merupakan suatu cara penyetaan gender dengan kaum laki-laki dalam segala bidang. gender yang merupakan pembedaan perempuan dan laki-laki yang merupakan aksi konstruksi sosial budaya. kesetraan dan keadilan gender merupakan kondisi relasi antara perempuan dan laki-laki sebagai mitra sejajar agar mendapat perlakuan yang adil untuk mendapat akses sumber daya, mengontrol, berpartisipasi, dan memperoleh manfaat pembangunan. ${ }^{8}$ Kemampuan perempuan untuk melakukan kegiatan dan banyak profesi layaknya lakilaki, menempatkan perempua sebagai tulang punggung keluarga khususnya dalam usaha pemenuhan ekonomi.

Menurut Hubeis (2010, p.125), pemberdayaan perempuan adalah "upaya memperbaiki status dan peran perempuan dalam 
pembangunan bangsa, sama halnya dengan kualitas peran dan kemandirian organisasi perempuan". Daulay (2006) menyampaikan bahwa program pemberdayaan perempuan di Indonesia pada hakekatnya telah dimulai sejak tahun 1978. Dalam perkembangannya upaya dalam kerangka pemberdayaan perempuan ini secara kasat mata telah menghasilkan suatu proses peningkatan dalam berbagai hal. Seperti peningkatan dalam kondisi, derajat, dan kualitas hidup kaum perempuan di berbagai sektor strategis seperti bidang pendidikan, ketenagakerjaan, ekonomi, kesehatan dan keikutsertaan ber-KB. ${ }^{9}$ Upaya pemberdayaan perempuan oleh pemerintah Indonesia dituangkan dalam bentuk Undang-undang maupun peraturan pemerintah yang berkaitan dengan pemberdayaan perempuan, sehingga proses pemberdayaan bagi perempuan terlindungi dan diatur dengan baik.

\section{Pengelolaan Zakat Produktif dan Kebutuhan Pemberdayaan}

Implementasi keseriusan pemerintah terhadap pengelolaan zakat di Indonesia disusunlah relagulasi yang berkaitan dengan pengelolaan zakat salah satunya Undangundang nomor 23 tahun 2011 tentang Pengelolaan Zakat kemudian dibuatlah Peraturan Pemerintah RI nomor 14 tahun 2014 tentang pelaksanaan Undang-undang nomor 23 tahun 2011 tentang pengelolaan zakat. Pada PP ini merinci dari pelaksanaan pengelolaan zakat yang ada pada masing-masing pasal dalam undang-undang nomor 23 tahun 2011, dalam pelaksanaannya lembaga zakat merujuk pada PP ini.

Beberapa kelemahan yang teridentifikasi dalam pengelolaan zakat di Indonesia antara lain: Pertama, soal kelembagaan. Saat ini belum ada kejelasan fungsi siapa sebagai regulator, siapa sebagai pengawas dan siapa sebagai operator. Kedua, belum ada strategic planning secara nasional baik penghimpunan maupun pendayagunaan. Ketiga, soal mekanisme pelaporan yang hingga saat ini belum ada yang jelas bagi 
Jurnal Hawa Vol. I No. I Januari-Juni 20IS

lembaga/amil zakat. Keempat, masalah hubungan zakat dan pajak dalam UU Nomor 38 tahun 1999 disebutkan zakat sebagai pengurang penghasilan kena pajak (PPKP), namun dalam prakteknya belum berjalan dengan baik. Kelima, mengenai sanksi. UU pengelolaan zakat yang ada baru mengatur sanksi bagi pengelola zakat. Padahal seharusnya sanksi diberikan kepada muzakki. Tujuannya untuk mengingatkan terhadap kewajiban muzakki yang tertunda. ${ }^{10}$ Melalui regulasi zakat inilah nantinya semua kelemahan yang terjadi pada lembaga zakat zakat atasi agar fundrasing zakat, infak dan sedekah lebih optimal.

Hikmah dan manfaat zakat merupakan perwujutan keimaman kepada Allah, untuk menolong dan membina para mustahik terutama fakir dan miskin ke arah kehidupan yang lebih baik dan lebih sejahtera sehingga dapat memenuhi kebutuhan hidupnya dengan layak dan dapat beribadah kepada Allah dan terhindar dari kekufuran.
Sebagai salah satu sumber dana pembangunan sarana dan prasarana seperti pendidikan, ibadah, sosial, ekonomi maupun pengembangan kualitas sumberdaya manusia muslim, dan memasyarakatkan etika bisnis yang benar, karena zakat bukanlah membersihkan harta yang kotor, akan tetapi mengeluarkan sebagian dari hak orang lain dari harta yang dimiliki dan zakat juga merupakan salah satu instrumen pemerataan pendapat. Dengan zakat dikelola dengan baik memungkinkan membangun pertumbuhan ekonomi, sehingga mendorong umat untuk mampu bekerja dan berusaha untuk memiliki harta kekayaan yang dapat memenuhi kebutuhan hidup diri dan keluarganya. ${ }^{11}$

Pengelolaan zakat produktif salah satunya dapat dilakukan dengan kegiatan community development. Gagasan dasar community development adalah untuk memfasilitasi masyarakat pada umumnya, bukan hanya sekelompok teknorat 
pembangunan agar dapat mengakses dan mengontrol seluruh tahapan program pembangunan. Penyebab utama tidak merata dan tidak adilnya hasil-hasil pembangunan adalah karena masyarakat pada umumnya tidak terlibat dalam seluruh tahapan pembangunan. Seluruh tahapan program pembangunan dirumuskan dan dilaksanakan secara oligarki, yaitu oleh teknorat pembangunan, sementara masyarakat pada umumnya hanya diposisikan sebagai penerima semua rumusan dan pelaksanaan program pembangunan tersebut. Akibatnya, pelaksanaan program dan kegiatan pembangunan bukan menguntungkan tapi malah merugikan masyarakat, seperti rumah yang menjadi tempat mereka berlindung dan sawah atau ladang yang menjadi tempat mereka bercocok tanam digusur atas nama pembangunan. Karena itu penting untuk diungkap tentang pengertian community development, sebagai dimensi yang harus diperhatikan dalam pelaksanaanmya, prinsip-prinsipnya, jebakanjebakan yang kemungkinan ditemukan dalam melakukan community development. ${ }^{12}$

Peraturan Manteri Pemberdayaan Perempuan dan Perlindungan Anak Nomor. 6 tahun 2015 tentang Sistem Pemberdayaan Perempuan dan Perlindungan Anak pasal 2 dijelaskan bahwa sistem pemberdayaan perempuan dan perlindungan anak bertujuan untuk meningkatkan kualitas hidup perempuan, anak dan kualitas keluarga; meningkatkan kapasitas kelembagaan pemberdayaan perempuan dan perlindungan anak di pusat dan di daerah termasuk pengembangan sistem data gender dan anak; serta memberikan perlindungan hak perempuan dan pemenuhan hak anak termasuk perlindungan khusus bagi anak dari berbagai bentuk kekerasan dan perlakuan diskriminatif lainnya. Untuk mewujudkan tujuan tersebut dilakukan melalui:

a. Memberikan akses kepada perempuan dan anak 
Jurnal Hawa Vol. I No. I Januari-Juni 2019

terhadap layanan pendidikan, kesehatan dan bidang strategis lainnya.

b. Mendorong keterlibatan perempuan dan anak dalam proses pembangunan

c. Memberikan pengetahuan, ketrampilan, nilai-nilai karakter, budi pekerti dan ketahanan keluarga

d. Mendorong programprogram yang dapat meningkatkan kemandirian perempuan di bidang ekonomi, hukum, sosial, budaya serta bidang strategis lainnya.

Undang-undang RI

Nomor 6 tahun 2014 tentang Desa pasal 1 dijelaskan bahwa pemberdayaan masyarakat desa adalah upaya pengembangan kemandirian dan kesejahteraan masyarakat dengan meningkatkan pengetahuan, sikap, ketrampilan, perilaku, kemampuan, kesadaran, serta memanfaatkan sumber daya melalui penetapan kebijakan, program, kegiatan, dan pendampingan yang sesuai dengan esensi masalah dan prioritas kebutuhan masyarakat desa.

Pengembangan dan pemberdayaan masyarakat membutuhkan perangkat dan kriteria yang tidak mudah. Sebagaimana diuraikan oleh TIM Nasional Percepatan Pembangunan Kemiskinan (TNP2K) bahwa kriteria dasar pemberdayaan masyarakat adalah pertama adanya partisipasi kelompok masyarakat miskin dalam penyelenggaraan program. Kedua, ditandai adanya penyediaaan alokasi dana secara langsung ke masyarakat, dan ketiga penyelenggaraan program yang ditandai oleh sistem yang transparan dan diawasi oleh pendamping serta masyarakat.13

Ketiga aspek di atas menjadi bagian penting dalam pelaksanaan program pemberdayaan khususnya perempuan. Menempatkan masyarakat miskin dalam program pemberdayaan perempuan sebagai objek dari program yang akan dilaksanakan, karena perempuan menjadi bagian 
yang sangat penting dalam sebuah keluarga untuk menopang ekonomi keluarga. Namun dalam pelaksanaannya seringkali program pemberdayaan tidak didampingi secara penuh oleh penyelenggara program karena keterbatasan sumber daya manusia yang kompeten dalam memberikan pendampingan, sehingga seringkali program pemberdayaan tidak mendapatkan hasil yang maksimal. Sementara program yang dibuat menginginkan hasil berupa peningkatan ekonomi masyarakat, khususnya keluarga agar benar-benar mampu mandiri secara ekonomi.

$$
\text { Pada }
$$

dasarnya

pemberdayaan masyarakat yang dilakukan oleh lembaga manapun di dunia selalu berupaya untuk mewujudkan kesejahteraan

masyarakat serta mengentaskan kemiskinan dalam masyarakat. Pemberdayaan masyarakat yang dilakukan harus didukung oleh program-program yang langsung didukung oleh program-program langsung menuju pada ketepatan sasaran. Ketepatan sasaran program tersebut harus dilandaskan pada arah yang strategis yaitu masyarakat sebagai pelaku utama; penyelenggaraannya yang bersifat parsipatif, akuntabel, transparan dan mempertimbngkan kesetaraan status manusia antara laki-laki dan perempuan serta adanya ketersediaan sumberdaya, sumber dana dan pendampingan yang konsisten. ${ }^{14}$

\section{Badan Amil Zakat} Nasional (BAZNAS) sebagai salah satu lembaga yang memiliki program pemberdayaan masyarakat melalui dana zakat zakat, infak dan sedekah yang diterima dari masyarakat. Program pemberdayaan zakat ditujukan untuk membantu masyarakat dalam meningkatkan ekonomi keluarga agar mampu mandiri dalam memenuhi kebutuhan keluarga. Program pemberdayaan zakat salah satunya bisa diterapkan terhadap perempuan yang menjadi sasaran program sebagai bagian dalam keluarga 
Jurnal Hawa Vol. I No. I Januari-Juni 2019

dalam membantu

meningkatkan ekonomi keluarga.

D. Hasil Penelitian dan Pembahasan

Program Pemberdayaan Zakat bagi Perempuan di Desa Bukit Peninjauan II Kecamatan Seluma.

Desa Bukit peninjauan II dengan jumlah penduduk sebanyak 1.818 jiwa memiliki potensi untuk mengembangkan zakat produktif kepada kaum perempuan yang rata-rata berprofesi sebagai ibu rumah tangga dan sebagian menjadi buruh tani sawah yang pekerjaan tidak tetap atau hanya melakukan pekerjaan buruh bila pada musim tanam dan panen padi saja, setelah itu para perempuan hanya di rumah saja menunggu penghasilan dari usaha kerja suami yang juga rata-rata menjadi buruh tani pada perusahaan sawit yang ada di sekitar Desa Bukit Peninjauan I Kecamatan Sukaraja kabupaten Seluma.

Ada beberapa kegiatan yang telah dilakukan oleh pemerintah bagi masyarakat Desa Bukit Peninjauan I, pada tahun 2016 telah diberikan bantuan dana berupa bibit tanaman sayur, pupuk dan peralatan tani yang akan dikembangkan masyarakat di sekitar rumah atau tanah yang mereka miliki, namun kegiatan ini tidak membuahkan hasil yang maksimal, hal ini terlihat dari kondisi masyarakat sekarang yang tidak lagi mengembangkan usaha pertanian sayur sebagaimana bantuan yang telah diberikan pemerintah sebelumnya. ${ }^{15}$ Kondisi ini mesti mendapatkan perhatian serius dari masyarakat, agar bantuan yang diberikan benar-benar mampu berkembangkan secara baik dan dapat meningkatkan ekonomi masyarakat secara berkesinambungan, oleh karena itu perlu pendampingan dari pemerintah khususnya Dinas Pertanian Kebupaten Seluma untuk memberikan edukasi kepada masyarakat mengenai cara bercocok tanam yang dapat menghasilkan, sehingga mampu memenuhi kebutuhan hidup mereka secara hari-hari dan mampu pula menopang ekomoni rumah tangga sebagai salah satu mata pencaharian. 
Perempuan Desa Bukit Peninjauan I yang pendidikan rata-rata tamatan Sekolah Menengah Atas dan Sekolah Menengah Pertama dalam mengembangkan program pemberdayaan memang membutuhkan perhatian khusus, karena perempuan di desa ini belum memiliki skill dalam bidang tertentu, rata-rata kemampuan yang dimiliki mereka peroleh secara otodidak karena kebiasaan yang dilakukan atau faktor keturunan. Berdasarkan kemampuan tersebut ada beberapa program pemberdayaan perempuan melalui zakat produktif yang bisa dilakukan bagi perempuan Desa Bukit Peninjauan I:

1. Pemberian bantuan modal usaha sayuran

Sebagian dari perempuan yang ada di Desa Bukit Peninjauan I merupakan pedagang sayuran keliling dengan menggunakan gerobak dan motor yang berjualan di sekitar desa dan pasar. Sayur yang mereka jual dibeli dari pedagang lain yang memasok sayuran yang berasal dari daerah lain seperti curup dan kepahyang. Modal usaha yang diberikan kepada para perempuan dapat digunakan untuk menambah jumlah dagangan yang dimiliki agar lebih variatif dan meningkat kualitas dan kuantitasnya. Perempuan yang bekerja sebagai pedangang sayuran kadangkala menjadi tulang punggung keluarga dalam memenuhi kebutuhan rumah tangga mereka. Diharapakan melalui bantuan modal usaha dapat meningkatkan ekonomi keluarga para perempuan.

2. Pemberian bantuan bibit dan peralatan pertanian

Secara umum perempuan Desa Bukit Peninjauan I memiliki kemampuan dalam bertani, namun belum mempu mengembangkan hasil pertanian hingga mampu menjadi pendapatan rumah tangga. Melalui bantuan bibit tanaman sayur, pupuk dan peralatan bertani diharapkan para perempuan mampu memanfaatkan pekarangan rumah untuk ditanami berbagai jenis sayuran untuk memenuhi kebutuhan rumah tangga dan membantu 
Jurnal Hawa Vol. I No. I Januari-Juni 20IS

ekonomi keluarga. Program bantuan zakat bisa berupa program lanjutan yang telah diberikan pemerintah sebelumnya, namun tidak berkembang. Melalui program zakat produktif bisa diberikan juga semacam pelatihan bagi perempuan tentang cara bercocok tanam dan memasarkan hasil tanaman, agar program bantuan zakat mampu berjalan secara maksimal dan berkesinambungan sebagai upaya peningkatan ekonomi para perempuan.

3. Pelatihan pengembangan usaha home industri

Sebagian perempuan di Desa Bukit Peninjauan I berprofesi sebagai pembuat kue-kue basah dan pengolahan keripik ubi. Hasil dari kegiatan rumahan yang dilakukan perempuan selama ini digunakan untuk menambah kebutuhan rumah tangga. Melalui kemampuan yang dimiliki ini menjadi potensi besar untuk dikembangkan melalui program pemberdayaan zakat produktif dengan memberikan pelatihan kepada para perempuan untuk bisa mengembangkan kegiatan home industri pembuatan kue basah dan keripik ubi agar produksi yang dihasilkan lebih variatif, teknik pengemasan dan pemasaran, karena selama ini yang dilakukan masih bersifat tradisonal dan diproduksi dalam jumlah yang terbatas, karena wilayah pemasaran masih di sekitar Desa Bukit Peninjauan I saja.

Tujuan pelatihan adalah memberikan keterampilan kepada warga perempuan dusun dalam pengolahan bahan pangan lokal dusun dan memberikan kontribusi dalam mengembangkan

keterampilan yang sudah dimiliki oleh tim. ${ }^{16}$ Dengan ketrampilan para perempuan dapat mengolah bahan pangan yang ada agar lebih baik dan memiliki nilai jula yang lebih tinggi. Sehingga melalui program pelatihan diharapkan para perempuan tidak hanya memasarkan hasil produksi di sekitar desa tetapi bisa dipasarkan hingga ke daerah lain maupun dijual secara online dengan teknik 
pengemasan yang lebih menarik.

4. Pelatihan kewirausahaaan bagi perempuan muda

Sebagian dari perempuan muda umur 18-30 tahun di Desa Bukit Peninjauan I dengan pendidikan rata-rata tamatan SMA berprofesi sebagai karyawan toko dan konter handphon di beberapa wilayah Kabupten Seluma dan Kota Bengkulu. Melalui program pemberdayaan zakat produktif bagi perempuan dapat diberikan pelatihan kewirausahaan bagi perempuan agar mampu mandiri untuk berwirausaha, bukan hanya menjadi karyawan toko milik orang lain. Dengan sistem informasi yang terus berkembang diharapkan perempuan muda di Desa Bukit Peninjauan I mampu mandiri dan dapat memanfaatkan media yang ada sebagai sarana usaha dan pemasaran. Pelatihan yang dapat dikembangkan bisa pelatihan menjahid, salon kecantikan, budidaya jamur tiram dan lain-lain.

E. Penutup
Berdasarkan pembahasan di atas makan dapat disimpulkan bahwa program pemberdayaan zakat yang dkhususkan bagi perempuan yang dapat dilaksanakan di Desa Bukit Peninjauan I Kecamatan Sukaraja kabupaten Seluma yaitu pemberian bantuan modal usaha, bantuan bibit dan peralatan pertanian, pelatihan pengembangan usaha home industri, pelatihan kewirausahaan. Kegiatan pelatihan yang diberikan dapat secara community development untuk meningkatkan partisipasi perempuan dalam setiap program pemberdayaan zakat yang dilakukan.

\section{DAFTAR PUSTAKA}

Badan Pusat Statistik Kabupaten Seluma, Kecamatan Sukaraja dalam Angka 2018, Tahun 2018

Buku Induk Penduduk WNI Desa Bukit Peninjauan I tahun 2015

CiD, DDR, Pebs-FEUI, Zakat dan Pembangunan; Era Baru Zakat Menuju Kesejahteraan Umat, Jakarta, 2008 dalam 
Jurnal Hawa Vol. I No. I Januari-Juni 2019

Amiruddin, Model-model Pengelolaan Zakat di Dunia Muslim, ejurnal.iaintulungagung.ac.id

Hafidhuddin, Didin, Zakat dalam Perkembangan Ekonomi Modern, Jakarta: Gema Insani Press, 2002

Hilyatun, Dewi Laela, Pemberdayaan Perempuan melalui Pendayagunaan Zakat, Yin Yang Jurnal Studi Islam, Genjer dan Anak IAIN Purwekerto, vo. 2 no. 2, 2014

Kementerian Pemberdayaan Perempuan dan Perlindungan Anak, Mencapai Kesetaraan Gender dan Peberdayaan Kaum Perempuan, 2017, http://www.kemenpppa.g o.id

Pemerintah Kecamatan Sukaraja Kabupaten Seluma, RPJMDES Bukit Peninjauan I Tahun 2015

Peraturan Pemerintah RI Nomor 14 tahun 2014 Tentang Pelaksanaan Undangundang nomor 23 tahun 2011 tentang pengelolaan zakat

Sri Marwanti, Ismi Dwi Astuti: Model Pemberdayaan Perempuan Miskin Melalui Penegmbangan

Kewirausahaan Keluarga Menuju Ekonomi Kreatif di Kabupaten Karang Anyar, SEPA : Vol. 9 No.1 September 2012

Saugi, Wilda dan Sumarno, Pemberdayaan Perempuan Melalui Pelatihan Pengolahan Bahan Pangan Lokal, Jurnal Pemdidikan dan Pemberdayaan Masyarakat, Vol. 2 Nomor 2 tahun 2015

TIM, Zakat Community Developmnet; Model Pengembangan Zakat, (Jakarta: Direktorat Jenderal Bimbingan Masyarakat Islam Direktorat Pemberdayaan Zakat, 2013), h. 59

Todaro, MP. dan Stephen C Smith, Pembangunan Ekonomi di Dunia Ketiga, Jakarta, Erlangga 2003

Undang-undang Nomor 23 tahun 2011 Tentang Pengelolaan Zakat 
Undang-undang RI No. 1 Tahun 2017 tentang Kesetaraan Gender, pasal 1

\section{Refrensi}

${ }^{1}$ MP. Todaro dan Stephen C Smith, Pembangunan Ekonomi di Dunia Ketiga, (Jakarta: Erlangga 2003), h. 93

2 Dewi Laela Hilyatun, Pemberdayaan Perempuan melalui Pendayagunaan Zakat, Yin Yang Jurnal Studi Islam, Genjer dan Anak IAIN Purwekerto, vo. 2 no. 2, 2014, h. 140

${ }^{3}$ Kementerian Pemberdayaan Perempuan dan Perlindungan Anak, Mencapai Kesetaraan Gender dan Peberdayaan Kaum Perempuan, 2017,

http://www.kemenpppa.go.id

4 Pemerintah Kecamatan Sukaraja Kabupaten Seluma, RPJMDES Bukit Peninjauan I Tahun 2015 h. 7

${ }^{5}$ Badan Pusat Statistik Kabupaten Seluma, Kecamatan Sukaraja dalam Angka 2018, Tahun 2018

${ }^{6}$ Buku Induk Penduduk WNI Desa Bukit Peninjauan I tahun 2015

7 Sri Marwanti, Ismi Dwi Astuti: Model Pemberdayaan Perempuan Miskin Melalui
Penegmbangan Kewirausahaan Keluarga Menuju Ekonomi Kreatif di Kabupaten Karang Anyar, SEPA : Vol. 9 No.1 September 2012, h. 135

8 Undang-undang RI No. 1 Tahun 2017 tentang Kesetaraan Gender, pasal 1

${ }^{9}$ Wilda Saugi dan Sumarno, Pemberdayaan Perempuan Melalui Pelatihan Pengolahan Bahan Pangan Lokal, Jurnal Pemdidikan dan Pemberdayaan Masyarakat, Vol. 2 Nomor 2 tahun 2015

10 CiD, DDR, Pebs-FEUI, Zakat dan Pembangunan; Era Baru Zakat Menuju Kesejahteraan Umat, Jakarta, 2008 dalam Amiruddin, Model-model Pengelolaan Zakat di Dunia Muslim, ejurnal.iaintulungagung.ac.id, h. 160

11 Didin Hafidhuddin, Zakat dalam Perkembangan Ekonomi Modern, Jakarta: Gema Insani Press, 2002, h. 14

12 TIM, Zakat Community Developmnet; Model Pengembangan Zakat, (Jakarta: Direktorat Jenderal Bimbingan Masyarakat Islam Direktorat Pemberdayaan Zakat, 2013), h. 59

13 TIM, Zakat Community Developmnet; Model Pengembangan....h, 97 
Jurnal Hawa Vol. I No. I Januari-Juni 2019

14 TIM, Zakat Community

Developmnet; Model

Pengembangan....h, 97

15 Nuriyani, penduduk

Desa bukit Peninjauan I,

wawancara, tanggal 14 April 2019

16 Wilda Saugi dan

Sumarno, Pemberdayaan

Perempuan ... 